\title{
I6
}

GESINE MANUWALD

\section{The Reception of Republican Comedy in Antiquity}

\section{Introduction}

Literary Roman dramas were originally produced for single performances at specific festivals (from about 240 BC); therefore reception initially did not extend beyond the immediate audiences. Hardly any information about reactions of spectators survives; it is likely that dramatic poets, producers, and organisers of festivals will have aimed at catering for the tastes of their audiences. Even though there was no entrance fee, presenting plays that went down well with the public was essential for poets and producers to further their careers and for organisers to make an impact. When, however, revival performances of existing plays began to emerge during the second century в С and dramatic scripts had become available as texts by the end of that century, dramas were gradually able to reach wider audiences.

From this period onwards there is increasing evidence for reactions to Republican palliatae (comedies in Greek dress) from a variety of people in different set-ups. ${ }^{\text {I }}$ Over time these reactions vary in quantity and quality and illustrate different kinds of engagement with the plays: beyond watching plays, they include the reuse of motifs and phrases (by poets and other writers), commenting and editing (by scholars), or reading and assessment (by individual spectators or readers). This chapter reviews the extant information on the reception of Republican palliatae from the earliest available evidence in the Republican period until Late Antiquity (c. fifth century AD).

${ }^{I}$ On the reception of Plautus and Terence, cf. J. Blänsdorf and E. Lefèvre in Suerbaum (2002) \I27, 222-7 and $\ 129,249-52$; for an overview and brief discussion of testimonia on the reception of Plautus and Terence in antiquity, cf. Ronconi (I970) and (I972); of Terence, cf. Marti (I974). 


\section{Reception at Performances}

Despite the almost complete absence of direct evidence on audience reactions in the early period, some comments and formal features in the dramatic texts as well as a few testimonia allow some conclusions.

For instance, Plautus' comedies in particular, but also Terence's prologues and epilogues, contain addresses to audiences. In addition to the conventional request for applause at the end (e.g. Plaut. Bacch. I2 I I; Most. I I 8 I; St. 775), Plautus' characters appeal to the audience's experiences, invite their views or reactions, or share their plans with them (e.g. Plaut. Most. 354-6I; 702-Io; Ps. 584-5). Such passages reflect an effort to involve audiences and to present something they can relate to. In the early temporary performance spaces audiences were presumably closer to the stage in a less formal auditorium and therefore could engage closely with performances. ${ }^{2}$

On an intellectual level, the prologues to Plautus' and Terence's comedies reveal that by this time not only dramatic poets, but also audiences had an understanding of generic conventions and entertained corresponding expectations, for instance concerning the stock characters in palliatae as well as the appropriateness of certain figures and events in comedies (e.g. Plaut. Amph. 50-63; Capt. 55-62, I029-36; Ter. Haut. 35-42; Eun. 35-4I). Dramatic experience on the part of audiences is corroborated by numerous so-called metatheatrical references, especially in Plautus (cf. Christenson in this volume).

Obviously, dramatists only address audiences present in the theatre, and conclusions on the general attitude to dramatic performances cannot be drawn on this basis. ${ }^{3}$ This is perhaps illustrated by the single Republican palliata for which some, albeit biased, information concerning the original performance survives, namely Terence's Hecyra (Ter. Hec. I-57). According to the prologue speaker, this play only got a full staging at the third attempt, earlier performances having been disrupted. These disruptions were caused by rumours (presumably launched by Terence's opponents) about other spectacles to be given in the same venue, such as boxing or tightrope walking; therefore people who were keen on those rushed in and started to fight for places with those who were watching Hecyra. This means (at least according to Terence's presentation of the matter) that there was a proportion of the populace who had come to see Hecyra, while other groups were more interested in other entertainments.

${ }^{2}$ On the set-up for performances in front of the temple of Magna Mater on the Palatine, the original venue for dramatic productions at Ludi Megalenses, cf. Goldberg (I998) (with references).

3 On the respective success of Plautus and Terence and on their popularity with audiences, cf. Parker (1996). 
Still, what is regarded as the most successful drama during the Republican period proper on the basis of external criteria is a comedy by Terence: according to information in the ancient tradition, his Eunuchus earned the poet an unprecedented high sum in fees and was soon given a repeat performance (Suet./Donat. Vita Ter. 3; Donat. on Ter. Eun., praef. I.6). That there was demand for additional performances of popular plays has also been inferred from the fact that the known instances of complete instaurationes, i.e. repetitions of entire festivals due to religious irregularities, fall within Plautus' lifetime. Hence these may have been arranged to give more people a chance to watch those plays. ${ }^{4}$ This would mean that individual plays were clearly identifiable as favourites, and measures were taken to satisfy public demand.

From the second century в с onwards revivals of plays at different festivals became possible. The most obvious example is the surviving prologue to Plautus' Casina, which does not go back to Plautus himself, but was written for a revival, generally dated to about a generation after the original performance. In this prologue, the organisers claim that they offer a Plautine play to the audience, since there is demand for 'old' plays, particularly Plautine ones, as these are enjoyed by audiences in contrast to the worthless new ones (Cas. 5-20). Irrespective of the fact that the organisers are trying to advertise the play, this shows that Plautus' comedies were still in the public consciousness and audiences were assumed to be so educated that one could successfully argue with differences in quality.

In the argumentative context of the Casina prologue, a particular preference for Plautus' plays is alleged; but there is also talk of a general superiority of 'old' plays and a previous 'flower of poets'. Indeed, revivals in the middle of the second century в с included Terence's comedies. The information offered by the surviving so-called didascaliae to Terence's plays, which give 'technical' details about a play's performances, points to revivals of Terence's comedies in the I4Os and early I 3 Os B C. ${ }^{5}$

Since new dramas continued to be produced during this period, revivals of 'old' plays and performances of 'new' plays existed side by side from about the second half of the second century в С until the end of the Republic. The process of distinguishing between these two types of plays may have started even earlier; already in Terence's time there was an awareness that plays 'become old' (inueterascere) by repeated performances and that an 'old' play (uetus fabula) contrasts with a 'new' play (noua fabula), for

${ }^{4}$ Cf. Owens (2000) 386 and n. 7 (with further references).

5 On the chronology of Terence's plays and their revivals (and the problems presented by the didascaliae), cf. the overview by Lefèvre in Suerbaum (2002) 236-7 (with bibliography). 
which different rules of composition and perhaps different performance contexts apply (e.g. Ter. Haut. 7, 29, 43; Hec. I-8, I2-I3, I 8-I9).

A flourishing culture of revivals of earlier plays is attested for Cicero's time. A number of Cicero's frequent references to (serious and light) drama suggest implicitly or explicitly that he has recent performances in mind, for instance when he mentions audience reactions to particular scenes or performances or talks about details of actors' behaviour (e.g. Cic. De Or. 2.193; Fin. 5.63; Tusc. I.I06). However, the overwhelming majority of Cicero's statements refer to serious drama (mainly tragedy), and there are only a few comments that seem to point to revivals of palliatae, where actors are mentioned or stage characters are referred to as examples (Cic. Q Rosc. 20: Plaut. Pseud.; Cic. Sen. 65: Ter. Ad.; Fam. 9.22.I). It is uncertain whether this distribution reflects the actual situation or is due to Cicero's prejudices or argumentative aims; yet, since he quotes from comedies on a number of occasions (without specific reference to performances), it is clear that comedies were still vividly present in the public conscience.

It is obvious, merely on the basis of the prologue to Plautus' Casina, that revivals were not necessarily re-performances of the 'original' play, but could be adapted to the requirements of a new context; this was all the easier since no 'standard' versions of the texts existed in those times. The effects of subsequent generations of actors and directors modifying the texts are still noticeable in the surviving scripts (see below). It is also likely that palliata comedies, like tragedies, praetextae and togatae (e.g. Cic. Sest. 106-26), were interpreted according to the historical and political circumstances in the late Republic, i.e. that individual lines might be applied to particular topical issues. In those cases well-known plays are given a new level of meaning, which need not agree with the one originally intended, but makes the pieces more relevant to contemporary audiences.

After the end of the Republican period there is no clear evidence of performances of 'old' or 'new' palliatae, apart from a revival of a togata, a Roman comedy, in Nero's time (Suet. Nero I I.2: Afranius' Incendium). Apparently, reception of comedies via performances was coming to an end, presumably owing to changes in public taste and general developments in literary, historical, and social circumstances. However, the practice of revivals and the corresponding selection had already contributed to creating a 'canon of classics' among Republican comedies.

\section{Reception within Dramatic Poetry}

In addition to statements within dramatic scripts pointing to certain audience reactions, the earliest indications that dramatic performances in 264 
Republican Rome were not one-off events but may have had a longerlasting impact consist of reactions of the Republican playwrights to each other. Poets had obviously noticed that from the second Roman dramatist onwards there was a Roman dramatic tradition, in addition to the Greek tradition.

For instance, it is noteworthy that a few titles (and fragments) of palliatae are ascribed to both Naevius (c. 280/60-200 BC) and Plautus (c. 250-1 84 вС) in the textual transmission (e.g. Carbonaria; Colax). Although the relative chronology cannot be established beyond doubt and the relationship between the two versions is not known, the second-century writer Aulus Gellius (see below) records that Plautus revised and refined plays of 'old poets' in his own style, which therefore became attributed to him (Gell. NA 3.3.I3). Such a procedure may apply to a comedy entitled Colax ('Flatterer'), based on a homonymous play by the Greek poet Menander, which is mentioned in the prologue to Terence's Eunuchus (Ter. Eun. 25-34). The precise interpretation of the Terentian passage is difficult; yet the likeliest reading is that Plautus had taken up a play by Naevius and adapted it, which therefore was an 'old play' according to Roman categories. This implies that at least Plautus regarded this 'old' play (like others) as so promising that he thought it worthwhile to adapt it and to present the revised version to contemporary audiences.

With reference to his own plays, Terence (c. I95/4-I 59 в C) discussed his methods of composition, justifying them against accusations raised by opponents. In this context he has the prologue speaker in his first play refer to Naevius, Plautus, and Ennius as paradigmatic predecessors and places himself in their tradition, which apparently contrasted with principles of some contemporary playwrights (Ter. An. I 8-2 I). In a later play Terence has the prologue speaker allude to the fate of his immediate predecessor Caecilius Statius (c. 230/20-I68/7 B ), who, like Terence, had problems obtaining a full staging of his plays at their first performances and was only eventually successful through the perseverance of their shared producer Ambivius Turpio (Ter. Hec. I4-27). While this is a different kind of relationship, it also shows that the first Roman comic poets remained in the public consciousness and could be used as authorities in an argument before contemporary audiences.

That later dramatists also took practical advantage of their predecessors' work is suggested by an author of the Historia Augusta, who records that comic writers liked to have some of their characters use established phrases and that a line in Terence's Eunuchus (Ter. Eun. 426) was coined by Livius Andronicus (Liv. Andr. Pall. 8 R. ${ }^{3}=6 \mathrm{~W}$.), with a similar situation applying to Plautus and Caecilius (SHA 30, Car. I3.5). 
On the other hand, Terence could apparently make the plausible claim that he had not known of earlier Latin plays, namely Naevius' and Plautus' versions of Menander's Kolax, but only of the Greek play (Ter. Eun. 25-34). In the same context it is reported that an opponent voiced criticism of Terence's play only after he had managed to sneak into a pre-performance (Ter. Eun. I9b-24). This invites the conclusion that there was an awareness of the existence of predecessors, but that their dramatic scripts were not yet generally available.

As a professional writer of fabulae palliatae Terence was followed only by Turpilius (d. Iо4/3 B C); and the fragments surviving from Turpilius' oeuvre do not mention Terence or obviously take up particular phrases from his works. Therefore one cannot establish Terence's ancient reception within his dramatic genre, but it is known that he was recognised across dramatic genres: Afranius, a writer of fabulae togatae and active in the second half of the second century в writers of light drama as an outstanding poet and a paradigmatic model (Suet./Donat. Vita Ter. 7). This comment, which is also the earliest known reference to Terence, shows the continuing influence of palliatae on subsequent dramas.

After the end of the Republican period no more palliatae were composed for full-scale production on stage, and what survives of dramatic texts written afterwards shows no signs of engagements with Republican palliatae. However, reception of these dramas in other forms continued (see below).

\section{Reception via Texts and Early Scholarship}

While initially the only way to get to know a play was by watching a performance, literary Roman drama was based on written scripts, provided by dramatic poets as the basis for producers. It is generally assumed that, originally, dramatic scripts remained in the possession of producers after the event; they might be used on other occasions or passed on to other producers, but were not made available to the general public.

At some point, however, dramatic scripts (of at least some plays) started to have a separate existence as 'texts': the second century в C saw the beginnings of scholarly criticism. Scholars started to gather texts, prepare editions and commentaries, discuss questions of authorship, assess playwrights, and assemble details of theatre history; a major stimulus seems to have been the fact that more and more comedies were ascribed to Plautus while it was known that not all of them could be genuine (cf. Gell. NA $3 \cdot 3 \cdot$ II). 
L. Aelius Stilo Praeconinus (c. I 54-90 B C), a grammarian and a teacher of Varro and Cicero, as well as his son-in-law Servius Clodius, tried to separate genuine from spurious Plautine plays (cf. Cic. Fam. 9.I6.4; Gell. NA 3.3.I, 3.3.I I-I2). Volcacius Sedigitus, Aurelius Opillus, and Manilius assembled catalogues of Plautus' plays; such catalogues are said to have attributed between 2I and roo comedies to Plautus (cf. Gell. NA 3.3.I, 3.3.II-I2; Serv. in Virg. Aen. I, praef. [p. 4, 1l. 87-9 edn Harv.]). The tragic poet Accius ( $170-$ c. $80 \mathrm{BC}$ ), who was also a scholar, compiled a list of Plautus' genuine plays (cf. Gell. NA 3.3.I, 3.3.9) and established a chronology of early dramatists (cf. Cic. Brut. 72-3). Volcacius Sedigitus drew up a canon of the ten best comic writers, in which Plautus comes second and Terence is sixth (fr. I $F P L^{3}=$ Gell. NA I 5.24). All these activities contributed to establishing a 'canon' of Republican comic poets. Terence's works were studied by ancient grammarians since the second century BC; ancient sources name Porcius Licinus, Volcacius Sedigitus, Santra, Cosconius, Varro, Fenestella, Vallegius, Maecius Tarpa, and Verrius Flaccus.

A particularly influential person in the late Republic was Cicero's contemporary, the polymath Varro. Like Cicero's friend Atticus, Varro revised the chronology of early dramatists (cf. Cic. Brut. 7 I-3), and he wrote several treatises on the theatre. Thus Varro settled questions of biography and dating and identified a group of twenty-one Plautine plays (fabulae Varronianae), whose genuineness was accepted by 'the consensus of everyone' (according to Gellius), though he believed that other plays were also genuine due to their Plautine style (cf. Gell. NA 3.3.I-4, 3.3.IO). Modern scholars assume that these twenty-one plays are the ones that have survived (almost) complete until the present day. Already in the second century CE Gellius thought that Varro's catalogue was more reliable than earlier lists of genuine works since it was based on internal criteria (NA 3.3.I-4). Cicero, influenced by Varro and Atticus, also discussed philological questions such as that of chronology (Cic. Brut. 7I-3; Tusc. I.3; Sen. 50).

That scholars in the first century в С studied early Roman drama so closely, apparently not regarding dramatic scripts as prompt books for performances, but as texts in their own right, helped drama to acquire a prestigious status and will have contributed to the preservation of texts. Because of the importance of this step it has been suggested that Roman drama as literature was not invented and created by dramatic poets active in the third and second centuries, but rather constructed by scholars in the first century в С, who endowed it with the corresponding status by exegetic activities. ${ }^{6}$ Even though this theory has its problems as a single explanation, it is clear that the step from

${ }^{6}$ Cf. Goldberg (2005), with the review by Feeney (2006). 
performances to reading and studying dramatic scripts cannot be underestimated as regards the assessment and approach to drama. From this period onwards, quotations and references to plays cluster around a select group of well-known dramas; obviously, a canon of works was being established.

\section{Reception among Literary People}

Apart from reception within the dramatic genre (see above), the earliest poetic reception of Roman comedy is found in the works of the satirist Lucilius, active in the second century в С. Lucilius critically confronted and discussed comedy, like other literary genres such as tragedy and epic; he seems to have found fault with comedy's overblown and unreal character. This is indicated by quotations of verses from various poets; ${ }^{7}$ and apparently he even recreated stock comic features from a palliata by Caecilius entitled Hymnis in his satires, imitating and exaggerating typical elements of comedy. ${ }^{8}$

Later, comedy continued to have an influence on related literary genres, such as love poetry, in both form and motifs. ${ }^{9}$ By such processes dramatic scripts acquired an additional role as sources and reference points; even though love poets of the first century в С and beyond reversed elements of Republican comedy, they seem not to have rejected the genre outright, but rather appropriated this model into their own poetry. ${ }^{\mathrm{IO}}$ Even Horace, whose assessments of early comedy in his literary works are not entirely favourable (see below), seems to have modelled the role and function of his father in the Satires on fathers in Terentian comedy (Hor. Sat. I.4). ${ }^{\text {II }}$

Another early sign of a poetic reaction to Plautus is a funeral epigram quoted in one of Varro's treatises and transmitted by Gellius (Gell. NA I.24.3); while it is doubtful whether these lines were actually written by Plautus as recorded by Gellius, they illustrate that shortly after Plautus' time there was a feeling that he was an outstanding representative of comedy and its style.

By Cicero's time, reading plays had become an established form of reception besides watching performances. Cicero assumes that men of his background will have read plays as well as seen them on stage (esp. Cic. Rab. Post.

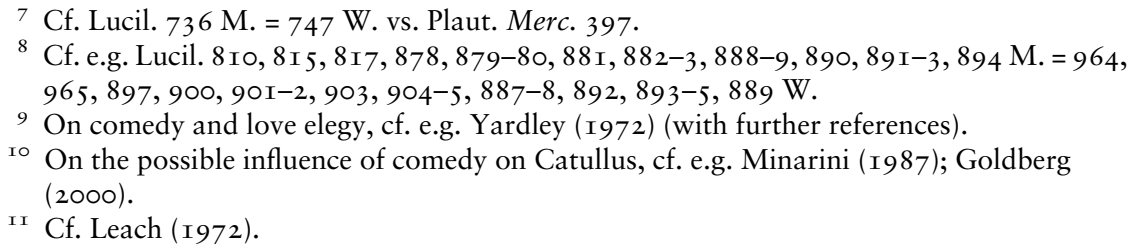


29; Fin. I.4-5; Acad. I.I0; Opt. gen. I8). He presupposes that his various addressees are familiar with the main representatives of Republican drama; for instance, he frequently does not mention the names of playwrights or titles or only quotes the beginning of a line or passage, assuming (explicitly or implicitly) that people will recognise the quotation and know what follows (e.g. Cic. Diu. 2.104; Planc. 59; Sest. I26; Tusc. 2.44, 4.77; Att. I4.I4.I; Fam. 9.22.I).

Cicero also voiced his assessment of poets (e.g. Cic. Opt. gen. 2) and discussed the contents of plays and their relevance to present-day audiences (e.g. Cic. Rosc. Am. 46-7; Q Rosc. 20; Planc. 59; Caec. 27; Tusc. I.3 I; Sen. 24): referring to a comedy by Caecilius, Cicero stated that characters on stage are well known, not different from real individuals and thus prototypical representations of ways of behaviour (Cic. Rosc. Am. 46-7). ${ }^{\mathrm{I2}}$ Cicero was aware of the fictitious character of stage drama (Cic. De Or. 2.193) and the poetic illusion in comedy (Cic. Tusc. 4.68); nevertheless, he believed that poets and actors empathised with their characters. Against this background he seems to have defined comedy as a 'mirror of life' (cf. Donat. Com. 5.I, 5.5) and regarded its language as close to everyday speaking (Cic. Orat. i 84 ). Cicero took views and attitudes of dramatic characters seriously, reflected on their considerations and the structure of their argument and engaged with their views on cultural, religious, or philosophical issues. ${ }^{13}$

Furthermore, Cicero started a process of reflecting on the poetic quality and position of Roman dramatic texts in comparison with their Greek predecessors. Since he came back to this issue several times, discussed it in prefaces to his own works, and commented on possible objections by people with different views, it is likely that this question was considered among educated people in his time. In comparing Latin dramas with Greek models Cicero stressed (in line with his own argumentative goal) that Latin versions are literary products worth reading for Romans (Cic. Fin. I.4-5; Acad. I.ıо; Opt.gen. I 8).

Concerning individual playwrights, Cicero noted the elegant wit of Plautus and the refined language of Terence (Cic. Off. I.IO4; Att. 7.3.Io; Suet./Donat. Vita Ter. 7 [Cic. fr. 2 FPL ${ }^{3}$ ]). Far more of Cicero's quotations from and references to palliatae are taken from Terence and Caecilius than from Plautus and Naevius. This probably indicates that

I2 Elsewhere Cicero claimed the same exemplarity for tragedy (Cic. Planc. 59; Rab. Post. 29; Sest. I02).

${ }^{13}$ For comments on drama in Cicero, cf. esp. Zillinger (I9II); Wright (I93 I); Laidlaw (I960); on the attitude to comedy in the first century в C, particularly in Cicero, cf. Blänsdorf (I974). 
Cicero found more material to illustrate his moral and philosophical arguments in their plays. This may be corroborated by the fact that Varro praised Terence for his character-drawing (Varro, Men. 399 B.; Charisius, Ars Gram., Gramm. Lat. I.241.27-9 Keil). Caesar, on the other hand, agreed with Cicero in his praise for Terence's language, but he regretted the lack of 'comic force' and therefore regarded Terence as a 'halved Menander' (Suet./Donat. Vita Ter. 7 [Caes. fr. I FPL ${ }^{3}$ ]). In the late Republican period, there was obviously not only philological study, but also aesthetic criticism.

\section{Reception of Comedy as a Benchmark of Roman Literary History}

Restrained language and sober style were presumably among the reasons why Terence soon became a school author in contrast to Plautus (and other writers of Republican palliatae), which led to numerous copies of the text of his plays.

In the Augustan age with its specific poetic and aesthetic criteria, Horace regarded Plautus' metrics, jokes, and delineation of characters as sloppy and not sufficiently polished (Hor. Epist. 2.I.I70b-6; Ars P. 270-4); he complained that Republican poets were highly regarded just because they were 'old' (Hor. Epist. 2.I.28-78). When it suited him, however, he adduced them as precedents: he pointed out that they were allowed to coin new words, and he demanded the same freedom for contemporary poets (Hor. Ars P. 53-5). He also recorded discussions about the relative merits of Republican poets and noted that Terence was regarded as outstanding in 'art' (Hor. Epist. 2.I.55-9). ${ }^{\mathrm{I}}$ Velleius Paterculus similarly saw Terence as a representative of a flourishing and more refined period of Roman drama (Vell. Pat. I.I7.I).

Later in the first century AD Plautus and Terence were still recognised as the main representatives of Roman comedy, but received mixed reception. In the overview of Roman literature within his treatise on the education of orators Quintilian voiced a general low opinion of Roman comedy, which was far behind Greek comedy, while he acknowledged that earlier generations had praised Plautus' language and ascribed Terence's writings to Scipio Africanus (Quint. Inst. I0.I.99-I00). Quintilian's younger contemporary Pliny the Younger on the other hand regarded Plautus and Terence as such authorities in the field of Roman comedy that he compared good-quality writing of his own time to this paradigm (Plin. Epist. I.I6.6, 6.21.2-5).

${ }^{\text {I4 }}$ On Horace's debt to Terence, cf. di Benedetto (I962); Calboli (I997). 
Republican comic writers, like all Republican poets, gained renewed appreciation in the second century AD, when the so-called archaists favoured the old (and by then old-fashioned) language of Republican times. ${ }^{15}$ Besides comments in Fronto (Fronto, esp. pp. 56.18-57.4 v.d.H.), who considered the language of Plautus as a model, the testimony of Aulus Gellius is significant: Gellius not only expressed his admiration for Plautus' language (Gell. NA I.7.I7, 6.17.4, I9.8.6, 20.10.2), but, through his own scholarly activities, also transmitted a considerable amount of information on the work of earlier scholars (see above) and quotations of poetic texts. Gellius' admiration for Republican poets, however, did not make him uncritical; for when he compared extracts from Menander's Plokion with Caecilius' version (Plocium), he thought that the Latin comedy read well on its own; however, the juxtaposition with the Greek version revealed its inferiority, since Caecilius had worsened Menander's text by inserting mime-like elements, tragic bombast, and a less coherent style (Gell. NA 2.23). That Caecilius might have pursued particular aims by these changes is disregarded by Gellius; at any rate this discussion shows that the question of the respective quality of Greek and Roman comedies was still of interest in the second century AD.

\section{Reception as Editorial Work}

While dramatic texts started to be worked on almost as early as dramatic scripts lost their character as ephemeral pieces for single events, there were no autographs and no standard editions straightaway. Those poets and plays that had made it into the 'canon' later received scholarly editions and commentaries; yet quotations reveal that other plays were still known in antiquity.

In the second half of the first century AD M. Valerius Probus produced reading texts of Republican authors, including Terence, accompanied by notes. Eventually, perhaps at the end of the first century AD, an edition seems to have been produced on the basis of the work done in establishing the genuine plays, on which the entire transmission ultimately depends. ${ }^{16}$ This edition reflected what was available at the time and was compiled according to the principle of preserving whatever was in circulation. It seems therefore to have included the genuine texts besides other versions, with the editor marking what he regarded as spurious: for instance, the text

I5 On Apuleius' debt to Plautus and his development of phrases in Plautine style, cf. e.g. Pasetti (2007).

${ }^{16}$ On the textual transmission of Plautus, cf. Tarrant (1983); also Deufert (2002); of Terence, cf. Reeve (I983) and Grant (I986); cf. also Radden Keefe's chapter in this volume. 
contained so-called actors' interpolations, i.e. additions and changes made at later revivals; these are evident by several versions of endings (cf. Plautus' Captiui, Poenulus; Terence's Andria) and by doubling of passages (cf. Plaut. Men. I037-44, repeated at 1028-9); in some plays sections are missing (cf. Plautus' Amphitruo, Aulularia, Bacchides, Cistellaria), while others clearly go back to revival performances (cf. Plautus' Casina). Hence, while ancient scholars debated which of the plays transmitted under Plautus' name were genuine, modern scholarly discussion has turned to the question of what constitutes the 'real Plautus', i.e. which sections of the transmitted dramatic scripts were written by Plautus. ${ }^{\mathrm{I} 7}$ On the other hand, this status of the text may provide glimpses into the performance history of the plays.

In the first decades of the second century AD Suetonius wrote a series of biographies including those of major Roman poets (De uiris illustribus). This work does not survive in full, but the life of Terence has been transmitted at the beginning of Donatus' fourth-century commentary (see below): this section includes details of Terence's life (some questionable) and a brief summary of views on Terence by early ancient writers.

The availability of editions for the main playwrights and the increasing distance from the time of composition in terms of language and cultural context presumably triggered the production of explanatory material on the works of those poets: a commentary on Plautus by Sisenna and comments by Q. Terentius Scaurus on Plautus'Pseudolus ${ }^{\mathrm{I} 8}$ as well as metrical plot summaries of the canonical plays are dated to the second century AD. Late Antiquity saw the emergence of manuscripts equipped with the names of poets and the titles of the dramas, plot summaries as well as lists of characters at the head of scenes.

Also in the second century AD the grammarian C. Sulpicius Apollinaris wrote plot summaries of twelve verses each for all of Terence's comedies (and perhaps more supportive material) for didactic purposes. At the turn of the century Helenius Acron and Arruntius Celsus each commented on some of Terence's plays. Aemilius Asper in the late second century, Euanthius and Aelius Donatus in the fourth century, as well as Eugraphius in the fifth/sixth centuries AD all compiled commentaries on the entire corpus. ${ }^{\text {I9 }}$ The works of

${ }^{17}$ The theory that the amount of genuine text is limited and a substantial part of the material dates from later hands, put forward by Zwierlein (I990-2) and Deufert (2002), is stimulating, but has not won general agreement.

I8 Cf. Charisius, Ars Gramm., Gramm. Lat. I.I98.24-6 Keil; Rufinus, Comm. in metra Terent., Gramm. Lat. 6.560.28-6I.Io Keil. On these writers, cf. Schmidt in Sallmann (I997a) $\$ 433$ (Q. Terentius Scaurus); \$445.I (Sisenna).

19 On these writers, cf. Schmidt in Sallmann (I997a) $\$ 436$ (C. Sulpicius Apollinaris), $\$ 444$ (Helenius Acron), $\$ 443$ (Aemilius Asper); Schmidt in Herzog (I989) $\$ 526.2$ (Euanthius), $\$ 527$ (Aelius Donatus). 
Donatus and Eugraphius survive; they seem to be compilations of material available in the grammatical tradition (with an emphasis on rhetoric in the case of Eugraphius), rearranged and supplemented by original comments, and also to have suffered in transmission. ${ }^{20}$ There are also extant scholia on Terence, often covering the same ground as the commentaries, but frequently with a particular twist. ${ }^{2 \mathrm{I}}$ Besides, a manuscript of Terence's comedies dating back to the fourth/fifth centuries AD and fragments of three others survive. Hence Terence is one of the few ancient writers for whom an ancient biography, a variety of ancient explanatory material, and manuscripts predating the Middle Ages are available. This is supplemented by numerous references and quotations in the secondary tradition.

\section{Reception among Christian Writers}

Republican comedy continued to be read until Late Antiquity (and beyond) as comments in a variety of late-antique writers demonstrate. Terence, along with Cicero, Sallust, and Virgil, was among the writers who were studied in school, often with the help of commentaries. In the fourth and early fifth centuries AD Lactantius, Ambrose, Jerome, and Augustine display a good knowledge of classical texts, ${ }^{22}$ like the pagan writers Ausonius (Auson. Epist. 20 Green; Protrepticus ad nepotem 45-60) and Sidonius Apollinaris (Sid. Ep. 4.I 2.I-2). While Christian authors did not approve of the contents, they relied on writers such as Terence for linguistic and literary education, although occasionally fears were voiced that the contents might have a detrimental influence on readers (cf. August. Conf. r.16.26; De ciu. D. 2.8). Theatrical performances of the classical type as well as the contents of the comedies were opposed by Christian writers since they regarded these events as pagan worship of the wrong divinities and the stories as offending Christian morality and setting negative examples (cf. e.g. August. De ciu. D. 2.7; Ep. 9I.4). A good case in point is Tertullian's treatise De spectaculis, dating to around $200 \mathrm{AD}$ : Tertullian reviews essential elements of performances at Roman festivals (alongside other spectacles) and criticises them from a Christian perspective, describing them as pagan worship and impure spectacles. As regards the stories and plots, Christians were upset especially

${ }^{20}$ For editions, cf. Wessner (I902/I905/I908); on Donatus' commentary, cf. Jakobi (1996).

${ }^{21}$ For editions, cf. Schlee (I 893); Mountford (I934).

22 On references of Christian writers to early Roman comedy, cf. Jürgens (I972) 88-I45; cf. also Rapisarda (1987); on Augustine's knowledge of Republican comic writers (mainly Terence), cf. Hagendahl (1967) 219, 254-64, and 377-83; Rosa (I987); on Jerome's knowledge and use, cf. Adkin (I994) and López Fonseca (I998); on Ambrose's references, cf. Courcelle (1972). 
by Plautus' Amphitruo, as they were enraged at this undignified presentation of gods (cf. Arn. Adv. nat. 4.35, 7.33; August. De ciu. D. 2.8).

However, the approach of Christian writers was not entirely dominated by ideological condemnation; at least some also engaged with the playwrights' literary techniques. According to his own admission, Jerome only turned from 'Ciceronianus' to 'Christianus' after a revelatory experience, whence he started to read Christian writings with great zeal (Hier. Ep. 22.30); and he was obviously familiar with early comic writers (Hier. Apol. contra Rufin. I.I3, I.I6). Importantly, Jerome, trained in exegetic and textual practices by his teacher Donatus (Hier. Eccles. I.9), regarded Republican Roman writers, including comic poets, as models for his method of translating the Bible: to translate from the original text and not from an earlier translation into another language (in contrast to Augustine's view: cf. August. Ep. 28), and, particularly, into a readable style according to the requirements of the target language (Hier. Ep. 57.5, 106.3.2-4; Comm. in Mich. 2, praef.).

\section{Conclusions}

Palliata, comedy in Greek dress in Rome, seems to have made a noticeable impact from the start and to have retained this influential position throughout antiquity, with the reception taking different forms and being of different intensity over the centuries. Reactions to individual poets and works during the creative period of Republican drama, within dramatic poetry and then also outside it, were followed by the first scholarly endeavours concerning the playwrights and their writings after dramatic scripts had become available as texts in their own right. A period of revivals from the second century в С until the end of the Republic coincided with reading and assessing the texts as well as increasing influence on other literary genres. When there were no longer full-scale performances of traditional dramas in the imperial period, palliatae were mainly received as objects of study, as school texts, as items for commenting and editing and as topics for discussion. While Republican dramatists were highly regarded in the period of Cicero and Varro, they were largely disapproved of from the Augustan era onwards, until they met with renewed appreciation from 'archaists' in the second century AD, only to be opposed again by Christian writers in the third and fourth centuries AD, albeit for different reasons.

Terence and also Plautus were transmitted as ancient 'classics' beyond the fourth century A D; they are mentioned in this role in Macrobius (Macr. Sat. 2.I.IO-II) and Sidonius Apollinaris (Sid. Carm. 2.I82-92); yet these lateantique writers seem to have had hardly any direct knowledge of the dramatic texts. This agrees with the fact that Rufinus, a writer of metrical 
treatises in the fifth century $\mathrm{AD}$, reported the view that the comedies were thought to be written without a metrical structure; to prove the contrary, he listed a number of authorities who stated that the works of Plautus and Terence as well as those by other comic and tragic writers were written in verse (Rufin. Comm. in metra Terent., Gramm. Lat. 6.564.20-5.5 Keil). The final item of (poetic) reception that could be classified as 'ancient' is the comedy Querolus siue Aulularia, written in Gaul in the fifth century AD, composed in prose and for recitation, based on Plautus and other ancient sources. Reception of Roman Republican comedy continued throughout the Middle Ages into the modern period (cf. the other chapters on reception in this volume).

\section{Further Reading}

Many books on Roman comedy, Plautus and/or Terence include some information on the reception of this dramatic genre and its poets; however, there is no comprehensive work on the reception of early Roman comedy, Plautus, or Terence in antiquity. The most useful overviews of the relevant passages illustrating the reception of Plautus and Terence, with brief discussion, are provided by J. Blänsdorf and E. Lefèvre at the relevant entries in Suerbaum (2002, in German), supplemented for Terence by Marti (1974, in German). Deufert (2002, in German) reviews the development of Plautus' comedies in antiquity from a textual perspective, with a view to separating the genuine from the spurious passages.

There are, at any rate, dedicated studies on various aspects of reception. The important period of the first century в C, represented particularly by the works of Cicero, is discussed by Zillinger ( I9 I I, in German), Wright (I93 I), Laidlaw (1960), and Blänsdorf (I974, in German).The textual transmission of the comedies by Plautus and Terence is summarised by Reeve (1983), Tarrant (I983), and Grant (I986). Information about the authors of lateantique commentaries can be found at the relevant entries in Sallmann (I997a and I997b, in German) and Herzog (I989, in German). The extensive extant work of Donatus is analysed by Jakobi (1996, in German).

Reactions of Christian writers to Republican comedy are surveyed by Hagendahl (1967), Jürgens (1972, in German), and Rapisarda (I987, in Italian). 